\title{
KEARIFAN LOKAL PELESTARIAN KAWASAN SEKITAR SITU CISANTI: SUATU KAJIAN UNTUK PENGEMBANGAN BAHAN AJAR
}

\author{
Local Wisdom Conservation in The-Surrounding Area of Situ Cisanti: A Study for Teaching \\ Material Development
}

\begin{abstract}
Abstrak
Kawasan sekitar Situ Cisanti berada pada arboretum 73, tepat di Hulu Sungai Citarum. Terdapat tujuh mata air yang mengalirkan airnya ke Situ Cisanti. Pengeringan mata air mulai terjadi saat kawasan sekitar diubah secara destruktif. Terganggunya ketersediaan air ini tentu merupakan suatu bencana yang harus segera diatasi. Metode yang digunakan dalam penelitian ini adalah kualitatif-verifikatif dengan pendekatan fenomenologi. Hasil yang diperoleh melalui kajian ini adalah meskipun aktivitas destruktif pada hutan di kawasan sekitar situ kerap terjadi, ternyata masih ada kearifan lokal yang diterapkan oleh masyarakat. Zonasi kawasan sekitar situ terbagi menjadi enam petak dengan tiga fungsi berbeda. Penelitian ini diharapkan menjadi inspirasi bagi peserta didik untuk lebih paham, sadar, peduli, dan tergerak untuk melakukan aksi pelestarian lingkungan. Bahan ajar dari hasil penelitian ini disesuaikan dengan materi ajar tentang pelestarian lingkungan pada pembelajaran IPS.
\end{abstract}

Kata Kunci : Kearifan Lokal, Pelestarian, Kawasan Sekitar

\begin{abstract}
The surrounding area of Situ Cisanti lies in the arboretum 73, precisely in the upstream of Citarum River. There are seven springs that flow their water into Situ Cisanti. These springs started to dry up when the surrounding area destructively altered. The disturbed of water availability is a disaster which must be resolved immediately. The method of the research is qualitative-verification through phenomenological approach. The result is, even though the destructive activities in the forest of the surrounding area of the Situ happens frequently there is still a local wisdom used by society in conserving nature. Zoning the around zone of the lake divided into six zones with the three functions. This research is expected to inspire the students to have a better understanding, be more conscious and care, as well as to take action in conserving the environment. Teaching material about environmental conservation for Social Science learning is made by developing the results of this research.
\end{abstract}

Keyword : Local Wisdom, Conservation, Surrounding Area

\section{PENDAHULUAN}

Air merupakan sumber daya alam yang utama bagi manusia. Ketersediaan air diperlukan tidak hanya dari segi kuantitas saja, namun juga kualitasnya (Burhan et al., 2017). Jika keseimbangan ketersediaan air terganggu, tentu akan menjadi bencana. Beberapa bencana seperti kekeringan, banjir ataupun permasalahan kualitas air biasanya disebabkan oleh kepentingan pribadi masyarakat yang tidak memperdulikan kelestarian air (Kodoatie \& Sjarief, 2005). Harus segera dilakukan penanganan terpadu dari berbagai unsur masyarakat dan pemerintah untuk pelestarian air, mulai dari sumber mata air di hulu sampai bagian hilirnya.

Hulu Sungai Citarum ini, secara administratif terletak di Desa Tarumajaya Kecamatan Kertasari Kabupaten Bandung. Situ Cisanti terletak di kaki Gunung Wayang 
(2181 mdpl) yang merupakan Gunung api aktif di kawasan Bandung pada titik arboretum 73 (Diana \& Pasha, 2015). Sebagai penampung mata air, Situ Cisanti harus dijaga kualitas dan kuantitasnya. Hal tersebut dikarenakan daerah pegunungan vulkanik disebut sebagai kawasan dengan mata air yang baik dan layak dikonsumsi yang memenuhi syarat karakteristik sumber air tanah yaitu kualitas, kuantitas dan kontinuitas (Ridwan \& Pamungkas, 2015).

Situ Cisanti dikelilingi oleh hutan dengan latar vegetasi hutan tropis yang rimbun dan tegaknya Gunung Wayang. Kawasan ini merupakan daerah resapan air bagi keberlangsungan pengaliran tujuh mata air yang di bendungnya. Mata air yang mengalir masuk ke situ yaitu mata air Pangsiraman, Cikahuripan, Cikawedukan, Koleberes, Cihaniwung, Cisadane, dan Cisanti (Wiranegara et al., 2018). Ketujuh mata air tersebut, pernah mengalami kekeringan saat aktivitas masyarakat untuk penggunaan lahan tidak terkendali. Peristiwa ini terjadi antara tahun 1994-2003. Kearifan lokal masyarakatlah yang mengembalikan fungsi ekologis hutan lindung untuk keberlangsungan pengaliran mata air Situ Cisanti.

Makna kearifan lokal dapat dipahami sebagai kemampuan berpikir, berasa, dan bertindak berkenaan dengan ide, gagasan, pandangan hidup tentang bagaimana manusia hidup dan berkehidupan. Kearifan lokal mampu menjadi filter dalam mengendalikan eksploitasi lingkungan. Kearifan lokal membawa pesan dalam rangka menyelesaikan permasalahan-permasalahan lingkungan (Kurniasari \& Reswati, 2011). Terjaganya kearifan lokal di suatu wilayah dapat menjadi bagian solusi permasalahan lingkungan.

Sedangkan menurut Marfai (2019) kearifan lokal dipahami sebagai suatu pemahaman kolektif, pengetahuan dan kebijaksanaan yang mempengaruhi suatu keputusan penyelesaian atau penanggulangan suatu masalah kehidupan. Kearifan lokal tidak saja berhenti pada dinamika etika, tetapi sampai pada norma, tindakan, dan tingkah laku, sehingga kearifan lokal dapat menjadi seperti tindakan spiritualitas yang memberikan pedoman manusia dalam bersikap dan bertindak, baik dalam konteks kehidupan sehari-hari maupun menentukan peradaban manusia yang lebih jauh.

Maka dapat disimpulkan bahwa kearifan lokal merupakan suatu pemahaman kolektif dalam berpikir, bersikap, dan bertindak dalam merespons dan mencari solusi permasalahan kehidupan. Termasuk di dalamnya permasalahan bencana lingkungan, di antaranya ketersediaan air. Pelestarian dalam penelitian ini maksudnya rangkaian upaya-upaya untuk memelihara kelangsungan daya dukung dan daya tampung lingkungan hidup terutama untuk menjaga keberlangsungan kawasan lindung Sekitar Situ Cisanti yang merupakan kawasan di sekeliling situ, mempunyai manfaat penting untuk mempertahankan kelestarian fungsinya.

Masyarakat Sunda biasanya mengenal sistem nilai dan kepercayaan dari individu manusia terhadap lingkungan. Menurut Iskandar (2011) “...sistem nilai dan kepercayaan tersebut diwujudkan dalam bentuk pantangan (pamali) dan penghormatan terhadap alam yang disakralkan (karamat) Hal tersebut adalah bagian penting dalam upaya mengelola dan menjaga kelestarian lingkungan...”. Keputusan penduduk dalam memanfaatkan 
sumber daya alam dan mengelola lingkungan sangat ditentukan antara lain oleh bagaimana sumber daya alam dan lingkungan dipersepsikan oleh penduduk lokal.

Bentuk adaptasi lokal orang Sunda yang dilestarikan di antaranya terwujud dalam petuah berbentuk peribahasa sejak zaman nenek moyang hingga saat ini. Endraswara (2013) mengemukakan salah satu peribahasa yang berhubungan dengan pelestarian alam di antaranya yaitu Gunung teu meunang dilebur, lebak teu meunang diruksak (Gunung tidak boleh dihancurkan, lembah/sumber air tidak boleh dirusak), Tatangkalan di leuweung teh kudu dipupusti (Pepohonan di hutan harus dihormati), Leuweung ruksak, cai beak, manusa balangsak (Hutan rusak, air habis, manusia sengsara).

Pelestarian lingkungan yang sesuai dengan peruntukan tata ruang diungkapkan dalam pepatah Sunda seperti dikemukakan Rohmat (2010) bahwa barangkali di antara kita sudah tidak ingat lagi atau bahkan belum tahu mengenai kearifan lokal masyarakat Jawa Barat (Urang Sunda) berikut ini: SAUR SEPUH Gunung kaian Gawir awian Cinyusu rumatan Pasir talunan Lebak caian Sampalan kebonan Walungan rawatan Legok balongan Dataran sawahan Situ pulasaraeun Lembur uruseun Basisir jagaeun (Gunung tanamlah pohon mata air peliharalah, tanamilah bukit dengan kebun campuran, lembah alirkan air, tegalan buatlah kebun, sungai peliharalah, cekungan buatlah kolam, dataran jadikan areal sawah, danau peliharalah, kampung diurus). Pepatah tersebut memiliki keluhuran nilai pelestarian alam yang menarik kita untuk merenung lebih dalam tentang bagaimana kita memperlakukan alam sekitar kita agar tercipta keselarasan yang pada akhirnya membawa hidup dan lingkungan kita nyaman dan damai.

Pepatah serta kearifan lokal lainnya dapat menjadi inspirasi bagi peserta didik untuk mengembangkan nilai kepribadian dalam berinteraksi dengan lingkungan. Senada dengan hal ini, Rahayu dan Sekarwinahyu (2011) menegaskan pentingnya ditanamkan sejak dini nilai-nilai lokal diangkat menjadi sumber pembelajaran. Peserta didik harus memahami bahwa manusia adalah agen pengubah lingkungan. Di tangan manusia, alam ini dapat menjadi kawan atau menjadi lawan. Adanya wawasan mengenai lingkungan, ilmu pengetahuan dan teknologi akan mengarah pada sikap pemeliharaan dan pelestarian lingkungan hidup. Selanjutnya Ningrum (2009) bahwa "pemanfaatan lingkungan sebagai sumber belajar dapat menumbuhkembangkan kecintaan dan kepedulian peserta didik terhadap lingkungan". Dengan demikian sumber daya alam yang ada dan tampak di sekitar lingkungan peserta didik, mereka akan lebih mengonstruksi konsep dan memahami proses yang terjadi di lingkungannya.

Maksud dari penelitian ini yaitu menganalisis kearifan lokal masyarakat sekitar untuk melestarikan kawasan sekitar Situ Cisanti, untuk mengetahui zonasi kawasan sekitar Situ Cisanti dalam mengurangi tekanan penduduk yang menggunakan lahan kawasan lindung, serta mengkaji implikasi hasil penelitian yang dapat dijadikan bahan ajar tentang pelestarian lingkungan. 


\section{HASIL DAN PEMBAHASAN}

\section{Kearifan Lokal Masyarakat Sekitar Situ Cisanti \\ Pembuatan Pagar Alam}

Penanaman rumput seluas 5 hektar dengan panjang mengelilingi kawasan yang dibuffer dengan lebar 20-50 meter, mengelilingi Situ Cisanti dan batas-batas setiap petak/zona. Terdapat pula buffer sekitar 1 meter yang membatasi tanaman Perhutani dan tanaman yang ditanam penduduk.

\section{Folklor/Cerita Rakyat Situ Cisanti untuk Pelestarian Kawasan Sekitar}

Cerita singkat dari folklor ini bercerita tentang seorang pemuda dari Galuh jatuh cinta pada seorang putri yang bernama Puteri Langka Ratnaningrum anak dari Pangeran Jaga Lawang yang tinggal di puncak Gunung Wayang. Saat menjelang pernikahan, penunggu Situ Cisanti Nyi Kantri Manik menggoda Gagak Taruna dengan kecantikannya. Gagak Taruna mengejar Nyi Kantri Manik di Tengah Situ, akhirnya meninggal dan tenggelam di tengah situ.

\section{Pupuh Sunda tentang Kawasan Sekitar Situ Cisanti}

Dinas Pariwisata Belanda di Indonesia pada tahun 1912 membawa serta Nyi Anah, Zangeres-Dichteres di Cianjur/juru mamaos Cianjuran mengunjungi daerah-daerah yang akan dituliskan dalam buku wisata wewengkon Pangalengan. Tulisan perjalanan Nyi Anah tertuang dalam bentuk pupuh atau tembang Sunda yang berupa 20 bait pupuh sinom, 16 bait pupuh asmarandana, dan 13 bait pupuh kinanti. Jadi jumlah seluruhnya 49 bait.

\section{Prasasti}

Di dekat gerbang pagar akan masuk ke Mata Air Pangsiraman terdapat prasasti yang dibuat oleh masyarakat dan pemerintah. Terdapat kalimat anjuran dalam 2 bahasa yaitu Bahasa Sunda dan Bahasa Sangsekerta. Prasasti ini dibuat untuk mengingatkan para orang yang berkunjung untuk selalu menjaga hutan agar negara menjadi makmur dan sejahtera.

\section{Wudhu diri}

Mandi untuk membersihkan diri dari kotoran dan dosa sebelum beribadah di dalam mushola di Cikahuripan mastaka citarum (air kehidupan hulu Sungai Citarum) yaitu Mata Air Pangsiraman. Ada langkah-langkah khusus untuk melakukan wudhu diri. Kegiatan ini dibimbing oleh kuncen. Pada proses ini, pengunjung tidak diperkenankan menggunakan detergen atau mengotori mata air. Gerakannya pun tidak membuat air keruh.

\section{Keberadaan Mata Air untuk Pelestarian Situ Cisanti}

Mata air yang mengaliri situ antara lain berasal dari mata air Pangsiraman, Cikahuripan, Cikawedukan, Koleberes, Cihaniwung, Cisadane, dan Cisanti. Mata air yang keluar dari tanah ini terlihat bening dan terasa menyejukkan. Dua mata air terbesar yang pengalirannya masuk ke Situ Cisanti yaitu Mata Air Blegblegan dan Pangsiraman (Gambar 1). 



Gambar 1. Mata Air Blegbegan (kiri) dan Mata Air Pangsiraman (kanan) Sumber : Dokumentasi Penulis (2020)

Kedua mata air inilah yang merupakan mata air terbesar, yang mengalirkan airnya ke Situ Cisanti. Warna air yang bening, air tanah tampak keluar dengan derasnya (ngaburial) hingga pasir-pasir di sekitarnya tampak tersembur. Sekilas nampak seperti air yang sedang bergolak.

\section{Ngabungbang}

Ngabungbang hampir sama dengan mandi wudhu diri yang dilakukan kapan saja, sedangkan ngabungbang dilakukan tepat pada malam 14 Mulud/Robiul Awal.

\section{Nadran}

Menebar bunga di mata air dan Situ Cisanti. Dilakukan sebagai bentuk penghormatan terhadap alam. Prosesi yang dilakukan di Cikahuripan Mastaka Hulu Citarum Pangsiraman.

\section{Petuah yang dianut masyarakat di sekitar Situ Cisanti}

a. Tong ngomong sompral (Jangan berkata sombong);

b. $\quad$ Tong make naon wae anu bakal ngotoran cai (Jangan menggunakan benda benda yang mencemari air);

c. Tong nguseup di situ (Jangan memancing di situ);

d. Tong dagang di sabudeureun situ (Jangan berdagang di sekitar situ);

e. $\quad$ Tong ngebak di situ(Jangan berenang di situ);

f. $\quad$ Tong nuar tangkal (Jangan menebang pohon);

g. Tong make syal warna beureum (Jangan menggunakan kain warna merah).

\section{Menerapkan Papatah urang Sunda (Nasehat Orang Sunda)}

Terdapat relevansi antara pesan karuhun dengan kondisi yang ada di lingkungan Situ Cisanti. Dari 12 pesan leluhur tersebut terdapat enam pelestarian. Berikut makna 6 dari 12 pesan yang mempunyai makna pelestarian di Situ Cisanti:

a. Gunung Kaian, yang mempunyai makna bahwa bentuk lahan yang berupa gunung harus ditanami pepohonan.

b. Pasir talunan, yang mempunyai makna bahwa pasir (bukit) harus ditanami.

c. Legok balongan, yaitu cekungan jadikan kolam untuk ditanami ikan. 
d. Cinyusu rumatan, yang memiliki makna mata air harus dijaga dan dipelihara. Upaya perlindungan yang ada di Situ Cisanti untuk mata air Pangsiraman yang disebut Cikahuripan Mastaka Citarum sudah sejak dahulu dilakukan.

e. Lembur uruseun, artinya kampung harus diurus. Perkampungan harus ditata dan dibuat nyaman.

f. Situ Pulasaraeun, artinya danau senantiasa dipelihara.

Pelaksanaan penataan Situ Cisanti dimulai tahun anggaran 2001, berupa pengerukan sedimen 3.636. $\mathrm{m} 3$ dengan pelaksanaan melibatkan masyarakat setempat, seperti pembersihan sekitar situ. Pembangunan situ ini menyerap tenaga kerja masyarakat perambah dan masyarakat setempat. Situ Cisanti ini wilayahnya berada di wilayah otoritas Perum Perhutani namun dipulasara (pelihara) oleh tiga institusi yaitu BKSDA, PJT II Jati Luhur, Perum Perhutani dan masyarakat sekitar. Dari hasil pembangunan Situ tersebut terlihat perbedaan nyata antara Situ Cisanti tahun 2001 dan Situ Cisanti sekarang ini, seperti dapat dilihat pada (Gambar 2) berikut ini :

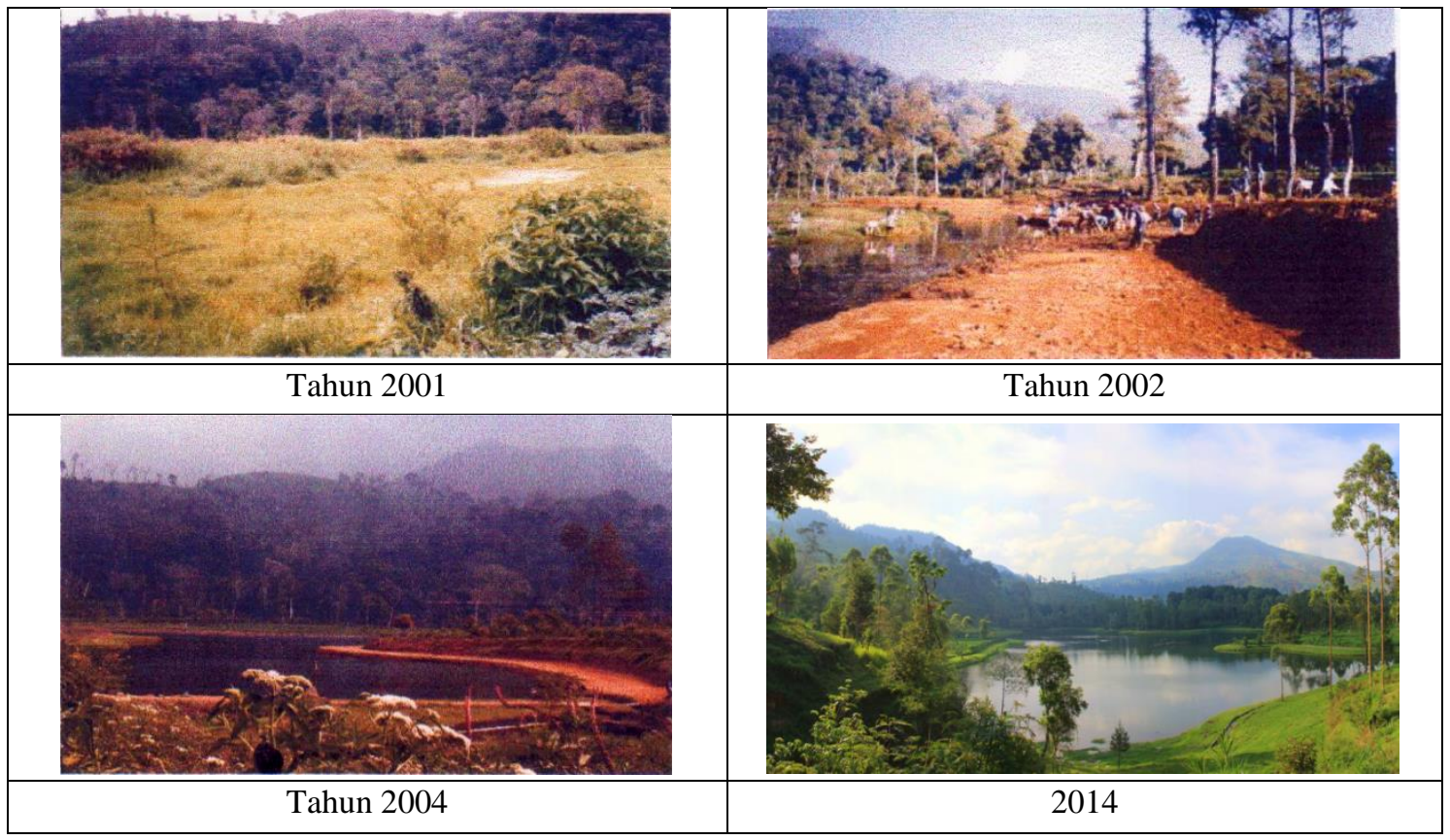

Gambar 2. Kondisi Situ Cisanti tahun 2001 sampai 2014

Sumber: BPSDAWS Citarum, 2001 dan Dokumentasi Penulis, 2020

Bentuk kearifan lokal di kawasan Situ Cisanti yang diringi dengan berbagai tindakan yang dilakukan secara terpadu oleh masyarakat dan pemerintahan terkait disandingkan dengan petuah karuhun (leluhur) urang sunda memiliki makna tersendiri untuk melestarikan kawasan Sekitar Situ Cisanti. Jika kearifan lokal yang dilaksanakan dengan pemahaman yang lebih mendalam dan penataan ruang yang tepat maka lingkungan sekitar Situ Cisanti akan senantiasa terjaga dan lestari.

\section{Zona Kawasan Sekitar Situ Cisanti}


Gunung Wayang dan Situ Cisanti setelah mengalami perambahan hutan yang puncaknya terjadi tahun 1998 sampai akhirnya pada tahun 2003 keluar Surat Edaran Gubernur Jawa Barat No. 522/1224/Binprod tanggal 20 Mei 2003 tentang Perlindungan dan Pengamanan Kawasan Hutan di Jawa Barat maka perambahan hutan harus dihentikan. Perambahan hutan dan alih fungsi lahan secara destruktif di lakukan oleh petani hutan mendorong keluarnya Surat Keputusan Menteri Kehutanan dan Perkebunan No. 419/1999 tentang perubahan fungsi kawasan hutan. Gunung Wayang sebelumnya merupakan kawasan hutan produksi, setelah keluar SK Menteri tersebut maka status hutan Gunung Wayang menjadi hutan lindung. Pada tahun 2003 status hutan Gunung Wayang menjadi hutan lindung, hutan produksi, dan hutan produksi terbatas dengan dikeluarkannya Surat Keputusan Menteri Hutan Nomor 195 tahun 2003. Kawasan lindung akan selalu berdampingan dengan kawasan budaya. Sesuai dengan UU Nomor 26 Tahun 2007 tentang Penataan Ruang, kawasan budidaya merupakan kawasan yang mempunyai fungsi utama untuk dibudidayakan. Sedangkan kawasan lindung, merupakan kawasan yang ditetapkan dan berfungsi utama untuk melindungi kelestarian lingkungan hidup, baik lingkungan alami maupun buatan. Berdasarkan Renstra Perhutani tahun 2008 - 2020 zonasi kawasan Sekitar Situ dibentuk dalam enam petak terlihat pada Tabel dan gambar 3 berikut :

Tabel 1. Zona-zona Sekitar di Kawasan Situ Cisanti

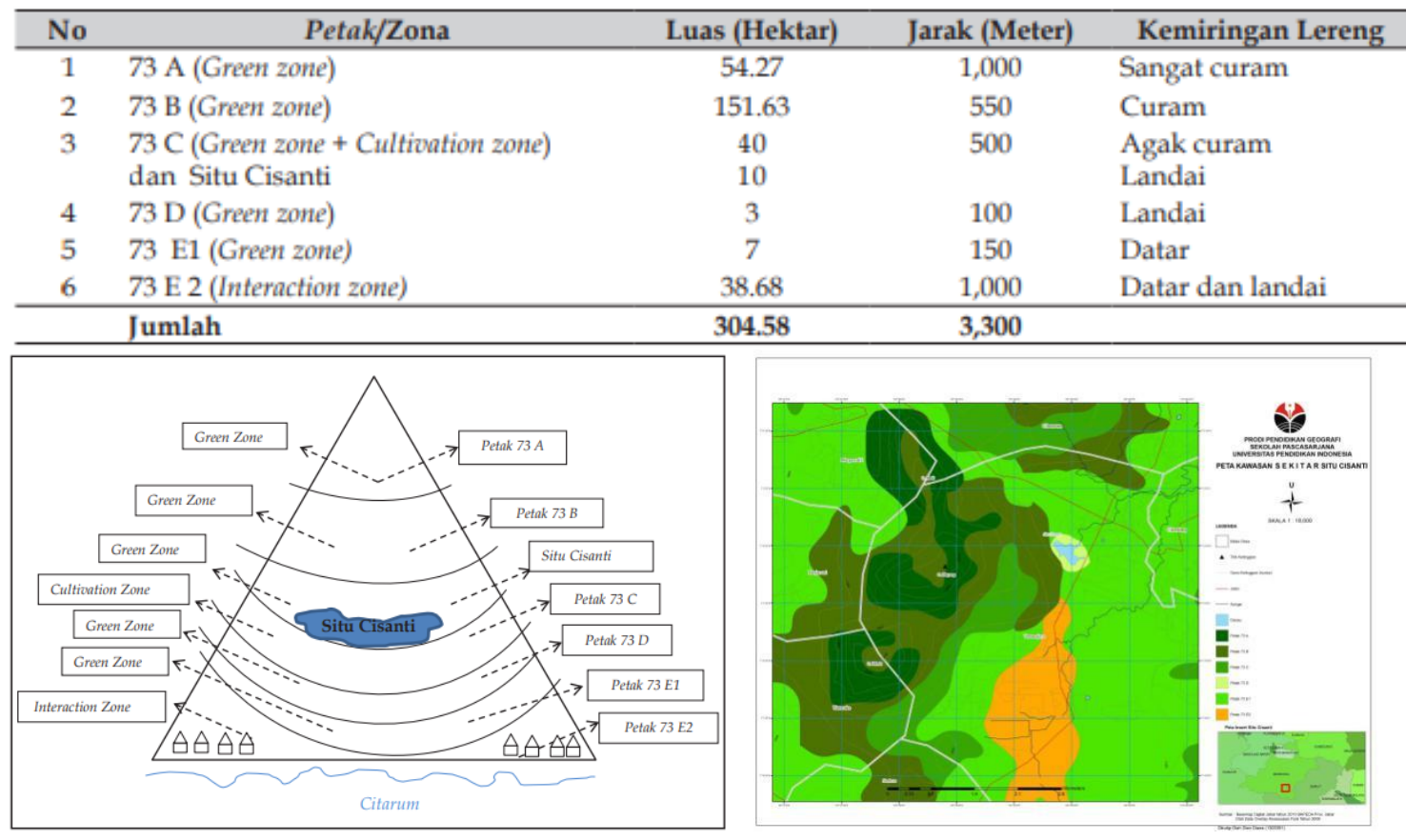

Gambar 3. Zonasi Kawasan Sekitar Situ Cisanti Sumber: Dokumentasi penulis, 2020

Gambar 4. Peta Kawasan Sekitar Situ Cisanti

Zonasi kawasan Sekitar Situ Cisanti yang merupakan hulu Sungai Citarum mempunyai Hak Pangkuan Desa (HPD) seluas 610 Ha, dan yang dikelola oleh Lembaga 
Masyarakat Desa Hutan (LMDH) Tarumajaya arboretum 73 dengan luas areal 265,91 Ha. Petak- petak dan fungsi zona pada tabel dapat diuraikan sebagai berikut :

1. Petak 73 A merupakan zona hijau memiliki luas wilayah 54,27 hektar terdapat Hutan Alam Kayu Lain (HKAL) dengan jenis pohon rimba campuran. Pada petak ini pohon-pohon yang ada tumbuh dengan sendirinya tanpa campur tangan manusia yang terbentuk secara alamiah.

2. Pada petak 73 B masih merupakan zona hijau dengan luas 151,63 hektar kelas hutan tanaman rimba campur termasuk di dalamnya tanaman kiara, pada zona ini telah ditanami tanaman buah seperti alpukat dan kopi, durian, petai, nilam, eukaliptus. Pada petak ini perum Perhutani dapat menambahkan tanaman kayu lain yang lain. Masyarakat tidak dilibatkan dalam kegiatan penanaman dan penggunaan lahan. Masyarakat hanya ikut mengawasi jika terjadi pelanggaran.

3. Petak $73 \mathrm{C}$ (cultivation zone) yang letaknya berdampingan dengan Situ Cisanti terhalang oleh hutan pinus, luasnya 40 hektar masih merupakan zona hijau. Namun masyarakat menggunakan lahan untuk agroforesty atau wanatani.

4. Petak 73 D memiliki luas sekitar 3 hektar dan ditanami oleh 11 jenis pohon pinus yang mengelilingi Situ Cisanti.

5. Petak 73 E1 berupa zona hijau seluas 7 hektar dengan vegetasi Hutan Alam Kayu Lain (HAKL) dengan pohon-pohon alamiah yang tumbuh dengan sendirinya.

6. Petak 73 E2 berupa zona interaksi (interaction zone) merupakan daerah untuk mendukung pengembangan sosial ekonomi masyarakat, pengembangan wilayah danwi sata, terdapat pula pertanian terpadu dan pemukiman. masyarakat terutama petani yang mengelola petak $73 \mathrm{C}$.

Zonasi dilakukan untuk melindungi lahan hutan agar sesuai dengan peruntukannya, keanekaragaman dapat terpelihara, fungsi hidro-orologi hutan terlaksana, keindahan alam terjaga, dan menghindari konflik kepentingan, sehingga akan tercipta pengekangan diri dan menempatkan kepentingan umum di atas kepentingan pribadi.

\section{Implikasi Hasil Penelitian untuk Pembelajaran}

Materi tentang pelestarian lingkungan secara umum mudah didapatkan dari berbagai sumber buku, namun kejadian secara kontekstual dalam lingkup lokal harus didapatkan langsung dari informasi wilayah tersebut. Salah satunya dari hasil penelitian tentang kearifan lokal pelestarian sekitar Situ Cisanti ini. Peserta didik dapat mengkaji lebih dalam melalui pembelajaran berbasis HOTS (High Order Thinking Skills) dengan pendekatan TPACK (Technological Pedagogical Content Knowledge) pada tema Hubungan Manusia dan Lingkungan. Hasil penelitian ini juga dapat disisipkan ke pembelajaran tematik yang berhubungan dengan pelestarian lingkungan. 


\section{SIMPULAN}

Kawasan Sekitar Situ Cisanti yang terletak di hulu Sungai Citarum keberadaannya sangat diperlukan untuk kesejahteraan masyarakat sekitar dan untuk kesejahteraan masyarakat di daerah tengah dan hilirnya. Walaupun banyak tantangan yang datang dari orang-orang yang hanya memikirkan kepentingan pribadi tanpa mempertimbangkan kondisi lingkungan yang ada dengan melakukan penyerobotan lahan dan merambah hutan dengan alasan memenuhi kebutuhan ekonomi, sehingga mata air yang mengalirkan airnya ke Situ Cisanti pernah mengering. Namun kearifan lokal yang masih dipegang masyarakat telah mengembalikan Situ Cisanti menjadi lingkungan yang lestari.

Kawasan sekitar Situ Cisanti yang berada di arboretum 73 secara terpadu yang penetapannya didasarkan pertimbangan pada tiga aspek yang saling terkait yaitu aspek ekologi, ekonomi, dan sosial budaya masyarakat. Zonasi pemanfaatannya terbagi menjadi 6 petak yang sebagian besar memiliki fungsi sebagai zona hijau. Hal ini menjadi satu keharusan karena kawasan ini menjadi daerah tangkapan hujan yang harus menyumbangkan airnya ke mata air yang pengalirannya masuk ke Situ Cisanti. Masingmasing petak berbeda penggunaan lahan dan fungsinya.

Hasil penelitian ini diharapkan akan membuka wawasan peserta didik tentang pentingnya menjaga lingkungan hidup dengan mengetahui dan memahami prinsip etika lingkungan yang diterapkan di mana pun mereka berada. Hasil penelitian ini dapat digunakan sebagai bahan ajar pembelajaran IPS dalam materi yang berhubungan dengan pelestarian lingkungan.

\section{DAFTAR PUSTAKA}

Burhan, N., Nagu, N., \& Anwar, C. (2017). Tinjauan instalasi pengolahan air bersih pdam di danau ngade. Jurnal Sipil Sains, 7(14).

Diana, D., \& Pasha, G. K. (2015). Pelestarian dan Peran Masyarakat di Kawasan Sekitar Situ Cisanti. SOSIOHUMANIKA, 8(2).

Endraswara, S. (2013). Folklor Nusantara. Ombak.

Iskandar, J. (2011). Upaya Pelestarian Tatar Sunda. Yayasan Rancage.

Kodoatie, R. J., \& Sjarief, R. (2005). Pengelolaan Sumber Daya Air Terpadu. Andi.

Kurniasari, N., \& Reswati, E. (2011). Kearifan Lokal Masyarakat Lamalera: Sebuah ekspresi hubungan manusia dengan laut. Buletin Ilmiah Marina Sosial Ekonomi Kelautan Dan Perikanan, 6(2), 29-33.

Marfai, M. A. (2019). Pengantar Etika Lingkungan dan Kearifan Lokal. UGM PRESS.

Ningrum, E. (2009). Kompetensi Profesional Guru dalam Konteks Strategi Pembelajaran. Buana Nusantara.

Rahayu, U., \& Sekarwinahyu, M. (2011). Penanaman Konsep Pemeliharaan Lingkungan di Daerah Rawan Banjir Melalui Pembelajaran Kreatif Produktif Berbasis Kearifan Lokal. Seminar Nasional FPMIPA-UT.

Ridwan, M., \& Pamungkas, D. W. (2015). Keanekaragaman vegetasi pohon di sekitar sumber mata air di Kecamatan Panekan, Kabupaten Magetan, Jawa Timur. Pros Sem Nas Biodiv Indon, 1.

Wiranegara, A., Hernando, A., Maghfyra, R., Farahyah, J. D., \& Nur, M. (2018). 
"Dampak Penggunaan Lahan terhadap Keanekaragaman Arthropoda pada Daerah Sekitar Situ Cisanti. Jurnal Penelitian Kecil Proyek Ekologi, 1-11. 